\title{
CARACTERIZACIÓN FISICOQUÍMICA DE TRES FUENTES SUBUTILIZADAS DE ALMIDÓN DE LA REGIÓN ANDINA DE BOLIVIA
}

\section{Carmen Carla Quiroga}

\section{RESUMEN}

Las características fisicoquímicas de tres almidones nativos de la región Andina de Bolivia: Achira (Canna edulis), Arracacha (Arracacia xanthorrhiza) y Jamachipeque (Maranta arundinacea), fueron investigadas. Las micrografías muestran que los gránulos de almidón de Achira son los más grandes, con tamaños entre $25-100 \mu \mathrm{m}$ y formas regulares ovaladas, los gránulos de almidón de Arracacha y Jamachipeque son menores en tamaño, 2 - $20 \mu \mathrm{m}$ y 4 $15 \mu \mathrm{m}$, respectivamente, y tienen formas irregulares poliédricas, siendo el tamaño de los gránulos del almidón de Jamachipeque más homogéneo que el del almidón de Arracacha.

El almidón de Achira contiene niveles altos de amilosa y fósforo, $34.82 \%$ y $0.0429 \mathrm{~g}$ de P/100 g de almidón. Los almidones de Arracacha y Jamachipeque tienen contenidos muy similares de amilosa y fósforo aunque menores a los del almidón de Achira, $15.13 \%$ y 0.0232 g P/100 g de almidón de Arracacha y $14.03 \%$ y 0.0205 g P/100 g de almidón de Jamachipeque. El contenido de humedad de los almidones nativos está entre $11.15-14.49 \%$ y el contenido de cenizas entre 0.19 y $0.45 \%$.

Los difractogramas de rayos- $\mathrm{X}$ de los almidones muestran que los almidones de Achira y Arracacha presentan una estructura cristalina del tipo-B y el almidón de Jamachipeque una estructura cristalina del tipo-A.

El proceso de gelatinización de los almidones inicia a temperaturas bajas, siendo la temperatura de empaste del almidón de la Arracacha a $50.8{ }^{\circ} \mathrm{C}$, Achira a $61.2{ }^{\circ} \mathrm{C}$ y Jamachipeque a $65.7{ }^{\circ} \mathrm{C}$, y las viscosidades máximas de $1113.0 \mathrm{mPa} . \mathrm{s}, 1930.0 \mathrm{mPa} . \mathrm{s}$ y $341.8 \mathrm{mPa} . \mathrm{s}$, respectivamente. El almidón de Achira muestra un mayor grado de retrogradación y el almidón de Jamachipeque una mayor estabilidad. Sin embargo, las curvas de flujo y viscosidad de las soluciones de almidón de Jamachipeque muestran un comportamiento Newtoniano con viscosidades bajas, a diferencia de las soluciones de almidón de Achira que muestra un comportamiento Pseudoplástico a concentraciones altas.

Palabras Clave: Achira - Cannaedulis, Arracacha - Arracacia xnathorriza, Jamachipeque - Maranta Arundinacea, Almidón Nativo, Raíces y Tubérculos Andinos. 